NBER WORKING PAPER SERIES

\author{
THE CHILD CARE INDUSTRY: COST \\ FUNCTIONS, EFFICIENCY, AND QUALITY
}

H. Naci Mocan

Working Paper 5293

\author{
NATIONAL BUREAU OF ECONOMIC RESEARCH \\ 1050 Massachusetts Avenue \\ Cambridge, MA 02138 \\ October 1995
}

This research is supported by grants from the Carnegie Foundation of New York, the Packard Foundation, and the Pew Foundation to the University of Colorado at Denver. Joseph Ron White, Danny Rees and Sarah Price provided outstanding research assistance at every stage of the project. I thank Tim Martin, Elena Pestchanskaia and Erdal Tekin for their assistance in the final stages of data clean-up. Earlier versions of the paper were presented at the 1995 AEA Meetings in Washington, DC, 1995 Western Economic Association Meetings in San Diego, and the University of Colorado at Denver. I am indebted to participants in those seminars. Anne Dryden Witte, Barbara Bergmann, Suzanne Helburn, John Morris, Alison Hagy, Bárbara Robles, W. James Smith, Madeline Mocan, Daniel I. Rees, and especially Jeff Zax and David Blau provided helpful discussions and comments. Any opinions expressed here are those of the author, and should not be assumed to be those of the granting agencies, University of Colorado at Denver or NBER. This paper is part of NBER's research program in Health Economics.

(c) 1995 by H. Naci Mocan. All rights reserved. Short sections of text, not to exceed two paragraphs, may be quoted without explicit permission provided that full credit, including $\odot$ notice, is given to the source. 


\title{
THE CHILD CARE INDUSTRY: COST FUNCTIONS, EFFICIENCY, AND QUALITY
}

\begin{abstract}
Using a newly compiled data set, this paper provides insights into the characteristics of the child care industry. First, there is no difference in average quality of the services produced between nonprofit and for-profit centers. This indicates that nonprofit status cannot be taken as a signal of higher quality. Second, the hypothesis of relative inefficiency of nonprofit centers with respect to for-profits is unfounded. On the other hand, centers that receive public money, either from the state or federal government, that is tied to higher standards, have variable costs that are 19 percent higher than other centers.

Child care workers with 13 to 15 years of education and workers with 16 and more years of education are substitutes. Both of these groups are complements to workers with 12 and less years of education. Centers have inelastic demand for workers.

There are economies of scale in production. Controlling for the level of quality of services, a 10 percent increase in hours of children served brings about only an 8.5 percent increase in costs in the long-run. There is no evidence of economies of scope. Serving various age groups jointly is not more efficient than serving them separately, although the issue is less clear in the case of preschoolers and school aged children.

The cost of increasing the quality of an average center from mediocre to good is between 12-16 cents per child-hour.

\section{H. Naci Mocan}

Department of Economics University of Colorado at Denver Campus Box 181, PO Box 1773364 Denver, CO 80217-3364 and NBER
\end{abstract}




\section{Introduction}

The increase in female labor force participation since World War II is one of the most significant changes in the Unites States labor market. Over the last two decades, this increase has been especially pronounced for married women with children. One of the consequences of this change has been the reallocation of child care and childrearing tasks. Since the mid-1970s, it has become increasingly common for children from all segments of society to be cared for by persons other than their parents (Blau and Hotz, 1992). The U.S. Department of Commerce reported that families with employed women spent an estimated \$21 billion on child care in 1988, and women in poverty pay approximately 21 percent of their family income for child care (U.S. Department of Commerce, 1992). Proposed welfare reforms are expected to further increase female labor force participation and the demand for market based child care.

Another important development in the U.S. labor market during the last decade is the increase in wage and income inequality (Levy and Murnane 1992, Murphy and Welsch 1992, Mocan 1995a). Inequality in wages and earnings increased significantly even within narrowly defined groups, suggesting that the growing demand for more skilled workers and the rise in the returns to skill are the main reasons for the increase in wage inequality (Burtless 1990, Moffitt 1990, Cutler and Katz 1991, Juhn, Murphy and Pierce 1993).

There is growing evidence linking the quality of childhood care and education to child development. High quality child care programs have been shown to reduce the likelihood of enrolling in special education programs (Lazar et al., 1982) and to improve the academic outcomes of children (Ramey and Campbell, 1991). Also, recent studies demonstrate the relationship between schooling, cognitive skills and labor market success (Murnane, Willett and Levy 1995, Coleman 1993, Angrist and Krueger, 1991).

Given the path from the quality of child care to child outcomes and children's future labor market achievement, it is critical to develop an understanding of the functioning of child care industry. First, it is documented by professionals in early care 
and education that the average quality of center-based care provided in the United States is below the level that is considered developmentally appropriate (Whitebook et al., 1990). This study confirms that finding, and estimates the costs associated with an increase in quality. Second, there exists a long-standing controversy in the child care industry about the performances of nonprofit and for-profit centers. Nonprofit centers are accused of being inefficient; i.e. receiving various donations from public and private agencies, but wasting those resources by producing child care services at higher costs than their for-profit counterparts. For-profit centers, on the other hand, are said to have lower quality, and therefore taking advantage of the consumers who cannot have perfect information about the quality of services purchased. This paper shows that both of these claims are incorrect. The paper also estimates demand elasticities of various types of labor and investigates the existence of economies of scale and scope in child care industry, which are important pieces of information if decisions about the type and scale of production are to be made to reduce costs.

\section{Background, Data and Improvements over Previous Work}

As Walker (1991) states, there exists only a handful of studies that investigate the supply side of the child care market. Powell and Cosgrove (1992) estimate a translog cost function using data from 182 child care centers accredited by the National Association for the Education of Young Children in 1989. They find that for-profit centers have costs that are 9 percent lower than their nonprofit counterparts. They also detect economies of scale in production. Powell and Cosgrove control for center quality by adding the child/staff ratio, the group size of children, staff turnover, experience and education to the cost equation and report significant relationships between these center characteristics and costs.

Mukarjee and Witte (1993) estimate a homothetic CES cost function for centers from the state of Massachusetts with data from 35 for-profit and 46 nonprofit centers. They report that the parameters of the cost function do not differ between for-profit and 
nonprofit centers and conclude that the observed higher costs for nonprofit centers result from different input and output choices, and not from differences in the method of operation.

Preston (1993) estimates an average cost function using data from a national survey conducted in 1976-1977. Using a sample of 2703 observations she finds that the production functions of nonprofit and for-profit centers are similar. She reports that nonprofit centers offer costlier services than for-profit centers and nonprofit centers provide higher quality services if federally regulated. Mukarjee and Witte (1993), and Preston (1993) also acknowledge the heterogeneous nature of the output, and control quality by including variables similar to the ones used by Powell and Cosgrove (1992).

This paper improves upon previous studies in a number of important ways, and provides new insights into the cost and production structure of the child care industry. First, it uses a new data set obtained from child care centers in California, Colorado, Connecticut and North Carolina.' The data are based upon a stratified random sample of approximately 100 day care centers from each participating state, with equal representation of for-profit and nonprofit programs, which provide full-time year-around care. Unlike other data sets currently available that are based upon telephone surveys (e.g the data of the Affordibility Study Team at Wellesley College, used by Mukarjee and Witte 1993), or questionnaires mailed to the centers (e.g. the GAO data set used by Powell and Cosgrove 1992), the data of this study are obtained by actual visits to the centers during the spring of 1993. Data collectors obtained in-depth financial information on center costs, amounts and sources of revenue, and amounts and sources of donations through on-site interviews and reviews of center records with center administrators or owners. Also, two observers visited each center for one day to gather data on classroom

1 The data are complied with the collaboration of economists, psychologists and child development experts from University of Colorado at Denver, Yale University, University of North Carolina at Chapel Hill and UCLA. 
and center structural and process quality. As a result, the extraordinary detail of the data allows for control of center quality, and the measurement of variables with more precision than was possible before. For example, many previous studies constructed the average wage rate of the center by dividing the wage bill to hours of labor. In this study information was collected on all workers in every center. ${ }^{2}$ Consequently, center average wages for various labor categories (by title, by education, etc.) can be created using micro data.

Another improvement over existing data sets is the detailed measurement of donations. Because donations are received more heavily by nonprofit centers, failure to account for the value of donations would create an inaccurate picture as to the relative costs of nonprofit centers. The data set contains information on line-item donations such as food, equipment, facilities, insurance and supplies. It also contains information about individual volunteers, including the hours donated by each volunteer, and the job performed at the center.

One other main aspect of this data set is the ability to distinguish between center structural and process quality. Although previous studies acknowledged the heterogeneity of the output produced, they lacked a good control of center quality. As a result, they attempted to control center quality by including various center characteristics, such as staff-child ratio, staff education and experience into the cost function as explanatory variables. These center characteristics, known as "structural quality measures" in early childhood education literature, are "inputs" into the production of center's "process quality". Classroom process quality is influenced by classroom structures such as teacher education, teacher experience, and the number of children per teacher, as well as by center structural characteristics such as the number of children

\footnotetext{
${ }^{2}$ More specifically, for every worker, the data set contains information on hourly wage or annual salary, hours of work per week, years of experience, tenure at the center, age, race, gender, the age group of children served and their job title.
} 
served, the age groups that are served. The center's process quality is also affected by the quality of child care environment, specific aspects of teacher-child interactions, and the style of teaching. ${ }^{3}$

This paper employs the index of process quality to control for heterogeneity in output. This index is widely used in early childhood literature, and has been shown to be positively related to children's social and cognitive developments. Later in the paper it is shown that the use of structural quality measures (such as the staff-child ratio) in a cost function is troublesome because of theoretical and statistical reasons. The paper demonstrates the bias that is generated by attempting to control quality using improper proxies.

The data contain information on actual hours of service provided for various age groups of children. Thus, a multi-product cost function is estimated, where the services for infant-toddlers, preschoolers and kindergarten-school age children are distinguished. As a result, this paper provides, for the first time, information on economies of scope in child care industry. Other contributions are the calculation of the cost of an increase in center quality, and economies of scale in production. Aspects of production technology, such as homotheticity and the separability of inputs, and the efficiency comparison between nonprofit and for-profit centers are also reported. Finally, this is the first paper to report elasticities of substitution among three labor categories, and the corresponding labor demand elasticities.

Section III describes the model estimated, Section IV explains the sample design and the measurement of variables. Section $V$ presents the empirical results, and Section VI is the conclusion.

3 See the Appendix for a description of structural and process quality instruments. $A$ detailed discussion of the relationship between process and structural quality can be found in Blau (1994) and Mocan, Morris and Helburn (1995) 


\section{Empirical Implementation}

The analyses are based upon the estimation of cost functions for child care centers. While the production function and the cost function are dual in theory, estimates of the stochastic forms need not be dual to each other. With a cost function one needs only to assume that firms are minimizing costs, while estimation of a production function requires the underlying, more stringent assumption of profit maximization (Hamermesh and Grant 1979). Given the existence of nonprofit firms in this industry, estimation of a cost function has more relevance. Second, in our context, estimation of a cost function has stronger statistical power. This is because the cost function is based upon the exogeneity of input prices, while the production function assumes that the quantity of inputs is exogenous. Given that our unit of observation is the firm, it is more reasonable to assume the exogeneity of wages rather than the exogeneity of quantity of labor hired.

The paper estimates short-run cost functions. Long-run cost functions are also important, but estimating a long-run cost function with these data may be problematic. Estimation of a long-run cost function would indicate that centers were in their long-run equilibrium. If this is not the case, i.e. if centers are off their expansion paths, the assumption of cost minimization is violated. This would imply misspecification of the long-run cost function and biased parameter estimates (Vita 1990, Nelson 1985). For child care centers, capital is not so much toys and equipment, as it is the physical plant. ${ }^{5}$ Unlike machinery, however, the expansion or contraction of the physical plant may be

4he possibility of wage endogeneity is explored later in the paper.

5 In our data set children's program supplies and equipment are reported as part of the operating costs. Some other components of the operating costs are office supplies, maintenance supplies, depreciation on equipment, transportation and travel, telephone, postage, licensing and fees, marketing, advertising and public relations. The ratio of operating costs to total costs was 8 percent. 
difficult. This is particularly the case if centers are using donated space. For example, if space is not easily divisible, then centers which receive donated space may be driven to use above-optimum physical capital. Thus, given the nature of capital in this industry, it may be difficult to obtain information about long-run equilibrium with these data. ${ }^{6}$ The second difficulty with estimating a long-run cost function involves the price of capital. A long-run cost function would treat capital as a variable input, and this necessitates the inclusion of the cost of capital as an explanatory variable, which is not available for centers that use partially or completely donated space. ${ }^{7}$

It should be noted that although a short-run cost function is estimated, following previous work (Noulas, Ray and Miller 1990, Callan and Santerre 1990, Vita 1990), inferences about long-run economies of scale and scope are reported as discussed below.

The short-run quality-adjusted cost function for child care centers can be expressed as

(1) $\mathbf{T V C}=\mathrm{f}(\mathbf{P}, \mathbf{Y}, \mathrm{K}, \mathbf{q})$,

where $T V C$ is the total variable cost, $P$ is the vector of prices, $Y$ denotes the vector of the quantity of outputs, $K$ stands for Capital, which is fixed in the short-run, and $q$ is the level of quality produced.

To estimate the cost function in equation (1), a translog functional form is employed. Translog cost functions have enjoyed wide-spread applications which include estimation of hospital cost functions (Vita 1990), cost of producing public safety (Gyimah-Brempong 1987), cost functions for the trucking industry (Gagne 1990), cost

${ }^{6}$ The same argument is made for electric power industry (Nelson 1985), hospital costs (Cowing and Holtmann 1983), and costs for school districts (Callan and Santarre 1990).

7 If the user cost of capital is the same among narrowly defined groups of centers, then estimating a cost finction with controls for auspice types and without capital may resolve this problem. 
functions pertaining to electricity and gas production (Betancourt and Edwards 1987), as well as cost functions for child care centers (Powell and Cosgrove 1992) and the nursing home industry (Gertler and Waldman 1992). A translog function is a second-order Taylor series approximation to an unknown, underlying, twice-differentiable function (Christensen, Jorgensen, and Lau, 1973). It does not impose any restrictions on elasticities of substitution among inputs and allows returns to scale change with respect to output. The empirical counterpart of equation (1) is the following translog cost function:

(2) $\operatorname{lnTVC}=\alpha_{0}+\Sigma \alpha_{i}\left(\ln P_{1}\right)+\beta_{1}(\operatorname{lnK})+\left(\beta_{2} / 2\right)(\ln K)^{2}+(1 / 2) \Sigma \Sigma \gamma_{y}\left(\ln P_{1} \ln P_{j}\right)+\Sigma \delta_{1}\left(\ln P_{i} \ln K\right)$

$+\Sigma \pi_{k}\left(\ln Y_{k}\right)+(1 / 2) \Sigma \Sigma \xi_{k r}\left(\ln Y_{k} \ln Y_{r}\right)+\Sigma \Sigma \mu_{\mu_{k}}\left(\ln P_{1} \ln Y_{k}\right)+\Sigma \phi_{k}\left(\ln Y_{k} \ln K\right)+\tau_{1}(\ln q)$

$+\left(\tau_{2} / 2\right)(\operatorname{lnq})^{2}+\tau_{3}(\ln K \ln q)+\Sigma \psi_{k}\left(\ln Y_{k} \operatorname{lnq}\right)+\Sigma \Omega_{i}\left(\ln P_{i} \operatorname{lnq}\right)+\Sigma \omega_{a} D_{a}+u_{i}$

where $T V C$ is total variable cost. $P_{i}$ and $P_{j}$ are prices of the ith and $j$ th inputs, respectively. They are the wages for teaching staff with 12 years or less formal education, wages for staff with 13-15 years of education, and wages for staff with 16 and more years of education.

Some studies used the number of full time equivalent children as the measure of output (e.g. Powell and Cosgrove 1992, Preston 1993). This is problematic, because the definition of full time equivalent is not the same across centers. There is significant variation in the length of a full time day across centers and across age groups. Thus, a more reliable measure of output is the actual hours of service provided. In this analysis output is classified into three categories: hours of infant-toddler services, hours of preschool services, and hours of before- and after-school services for school-aged children. $Y_{\mathrm{r}}$ and $Y_{\mathrm{r}}$ represent the amounts of the $r$ th and $k$ th output. $K$ stands for the amount of physical space, which is fixed in the short-run, $q$ is the process quality of the center. A vector of dummy variables $\left(D_{\mathrm{a}}\right)$ representing center attributes is included to capture efficiency differentials due to center characteristics. The variables are defined in detail in the data section below.

To be consistent with economic theory, the cost function should be linearly 
homogenous in input prices, and the cross-coefficients must be symmetric. These imply the following restrictions on Equation (2).

$\Sigma \alpha_{\mathrm{i}}=1, \Sigma \Sigma_{\mathrm{j}} \gamma_{\mathrm{ij}}=0$ for all $i, \Sigma \delta_{\mathrm{i}}=0, \Sigma \Omega_{\mathrm{i}}=0$, and $\Sigma \mu_{\mu_{\mathbf{k}}}=0$ for all $k$;

$\gamma_{i j}=\gamma_{j i}$ for all $i$ and $j$, and $\xi_{k x}=\xi_{i k}$ for all $k$ and $r$.

Using Shephard's Lemma, optimal demand for the ith input is obtained by differentiating the cost function with respect to the price of the ith input $(P)$ which yields:

(3) $\partial \ln C / \partial \ln P_{i}=\left(\partial C / \partial P_{i}\right)\left(P_{i} / C\right)=P_{i} X_{i} / C$,

where $\mathrm{X}_{\mathrm{i}}$ is the optimal level of input $i$. Thus, $\mathrm{P}_{\mathrm{P}} \mathrm{X}_{\mathrm{l}} / \mathrm{C}$ is the share of the input $i$ in total variable cost. Letting $S_{1}$ denote the cost share of input $i$, and differentiating the cost function depicted in (2) with respect to $P_{1}$ yields the following structure for the cost shares:

(4) $S_{i}=\alpha_{i}+\Sigma \gamma_{i j} \ln P_{j}+\Sigma \delta_{i} \ln K+\Sigma \mu_{i \mathrm{i}} \ln Y_{k}+0_{i} \ln q$.

The cost equation is estimated jointly with the system of share equations depicted in (4). To avoid singularity in the error covariance matrix, one of the share equations is deleted and the model is estimated using non-linear methods subject to the restrictions imposed above. The explanatory variables are normalized by dividing each variable by its mean before taking the natural logs (Callan and Santerre 1990, Vita 1990). ${ }^{8}$

Not all centers in the sample serve all three age groups. However, to obtain global information on the production function, it is necessary that the centers with zero output levels be included into the analysis (Caves et al. 1980, p. 478). Following Caves et al. (1980) Vita (1990), and Callan and Santerre (1990), the Box-Cox transformation

Because the translog cost function is a second-order approximation to an arbitrary cost function, its ability to represent the firm's technology is more robust at the point of approximation, which is the sample mean. Translog and other flexible functional forms may perform poorly for data points far from the approximation point (Vita 1990. Caves and Christensen 1980, Wales 1977). Furthermore, normalization of the explanatory variables generates the convenience that the first-order parameters are elasticities when evaluated at the means. 
is applied to the output variables, where $\ln Y_{i}$ is replaced with $\left(Y_{i}^{\lambda}-1\right) / \lambda$, and the Box-Cox parameter $\lambda$ is estimated jointly with other coefficients of the system.

\section{Sample Design and The Measurement of Variables}

Data were collected through visits during the spring of 1993 to approximately 50 randomly chosen for-profit centers and 50 nonprofit centers in all four states: California, Colorado, Connecticut and North Carolina, ${ }^{9}$ Only state-licensed child care centers offering services at least 30 hours per week and 11 months per year were included. The centers had to be in operation at least one full fiscal year immediately prior to data collection, and the majority of children had to attend at least $\mathbf{3 0}$ hours and five days per week in order to be included.

TVC is total variable cost of the center during the fiscal year 1991-1992. It is the sum of annual wage and salary expenditures, nonwage benefits, staff education costs, subcontracting costs, food costs, other operating expenses, and the estimated value of in kind donations (food, volunteer services, and supplies). The value of donations is included to make the total variable costs of different centers comparable to each other. The value of volunteer services is calculated by multiplying the volunteer hours by the wage rate of the paid labor doing similar work.

To the extent that the centers can alter the hours of work provided by the center's director(s), the salaries of the directors are also part of the total variable costs. Some for-profit centers are owned and operated by individuals who are also the directors of the center. For those owner-directors who did not report a wage or salary, the salaries are imputed and added to the total variable costs. Missing salaries of owner-

9 The Los Angeles county in California, the Front Range region in Colorado (Colorado Springs, Denver, Fort Collins), the Hartford-New Haven corridor in Connecticut and the Piedmont Triad area in North Carolina (Greensboro, Winston Salem and High Point) are sampled. 
directors are imputed by multiplying their hours by the highest wage at the center plus 23 percent, which is the mean premium a director receives above the highest wage of the center. To check the sensitivity, missing salaries were also imputed by (i) assigning the average salary of administrative directors in the same state, same sector (profit or nonprofit) and similar center size, (ii) by multiplying the highest wage at the center with the hours worked by the owner-director. The results were insensitive to the method. The overhead costs, facilities cost, and insurance costs are considered fixed costs. The overall sensitivity of the results to changes in the ingredients of TVC is discussed in the results section.

Each member of the teaching staff is classified into one of the three categories: staff with less than or equal to 12 years of formal education, staff with 13-15 years of education, and staff with 16 and more years of education. Workers who have special training and certificate degrees are promoted to the next category. For example, workers who have 12 or less years of education, but who have CDA training are promoted to the second level. Workers with an education of 13-15 years, and who have a Registered Nurse degree are promoted to the third category. For each group, center average wages (WAGE1, WAGE2, WAGE3) are calculated using individual wages, weighted by hours of work. For centers which do not have any staff in a particular category, the mean wage for that state is substituted.

Infant/toddler output (INFANT-TODDLER) is the total annual hours of service the center provided for infant-toddlers in the fiscal year. PRESCHOOL is the annual hours of service provided for preschoolers, and SCHOOLAGE stands for the annual hours of care provided for kindergarten-school age children. Centers that are observably identical in every respect (including quality) may have different costs in the presence of different, unobservable center characteristics. Because of these concerns, in equation (2), $D_{n}$ stands for the variables that capture the efficiency differential due to the structure in which the center operates. In this group of variables there is profit status (PROFT), which takes the value of 1 if the center is for-profit, and 0 if it is nonprofit. NATIONAL 
CHAIN is also a dichotomous variable, indicating whether the center is part of a forprofit national chain. SPECREG is 1 if the center receives public money, either from the state or federal government, tied to higher standards (above and beyond normal licensing regulations), and 0 otherwise. This group includes Head Start centers, centers where 20 percent or more of their enrollment constitute special needs children, special preschool programs sponsored by State or Federal Department of Education, and other special programs in Connecticut and California. PUBAUSP is set to 1 for centers that are owned and operated by public agencies. Examples include public colleges, hospitals, and city departments of family services. PUBSUPP is another dichotomous variable which takes the value of 1 if the center is not publicly owned or operated, but receives more that 50 percent of its revenue from public grants public fees and USDA reimbursement. Also included are the state dummies which aim to capture state-specific unobservables such as variations in regulatory environment. SPACE is the square footage of the inside space used by children, which is the measure of physical capital (K). It is obtained from the records of the center. In cases where it was not available, the observers measured the square footage of the center.

In each center two classrooms were randomly selected: one from the older children (30 months and older) and one from the younger groups. In each room wellestablished global measures of child care process were employed by trained observers to assess the quality of the operation. ${ }^{10}$ To create a single score to represent classroom process quality, an index was created using principal components techniques. The center level process quality (QUALITY) is the average classroom quality, weighted by enrollments at the appropriate age levels. This is the same quality index that has been widely used in child development literature, which has a seven point scale, with a range from inadequate (1) to minimal (3), good (5) and excellent (7).

10 See the Appendix for the details. 
Quality has dimensions that include parents' preferences concerning child care arrangement, such as whether the provider shares the same religion and values of the parents (Blau 1991). These aspects of child care, which create utility for parents, are expected to impact the demand for child care. This implies that a particular consumer's perception (or assessment) of quality of a given center may diverge from the child care experts' evaluation, as represented by our quality index. Nevertheless, the process quality index employed in this paper is the best measure to control for heterogeneity in output; and it is well suited for our task, because the investigation pertains to the supply of child care.

The descriptive statistics are presented in Table 1. In the full sample, nonprofit centers pay higher wages to workers than for-profit centers in each education category, although the difference for workers with less than 13 years of schooling is not significantly different from zero. For-profit centers serve more child-hours for infanttoddler and school aged children. There is no statically significant difference in the mean values of total variable costs, preschool hours produced, and the space used between the two sectors.

The sample average of the quality index is 4.01 , reflecting mediocre quality of care. The average quality of for-profit centers is lower than that of nonprofits. The difference, however, is due to the quality difference between the two sectors in North Carolina. Table 2 presents the descriptive statistics of quality, total variable costs and wages by state and profit status. There is no significant difference in quality between for-profit and nonprofit centers in California, Colorado and Connecticut. North Carolina for-profit centers have significantly lower average quality than their nonprofit counterparts, which may be attributable to relatively lax regulations in North Carolina in comparison to other states in the sample. The mean values of variable costs do not differ by profit status within a given state. The wages of the least educated workers do not differ by profit status, except in Colorado, where nonprofit centers pay more than for-profit centers. Wages of workers with 16 and more years of education are higher in 
nonprofit centers in all four states. The same is true for workers with 13 to 15 years of education, with the exception of California, where no significant difference is present. In short, Tables 1 and 2 demonstrate that with the exception of North Carolina, average quality is the same between for-profit and nonprofit centers, nonprofits pay higher wages to educated workers, for-profits produce more child-hours of service and the total variable costs are not noticeably different between sectors.

The equality of average center quality between for-profit and nonprofit centers is important. Child care is an example of a trust good, where the quality of the product is important to the buyers, but difficult for them to assess accurately (Weisbrod 1988). Because trusting the provider is important, consumers would need indications or signals of quality to help in their choice of provider. Tables 1 and 2 show that nonprofit status should not be considered as a "trust signal" for quality in the child care market."

\section{Empirical Results}

\section{Functional form}

The estimated cost function can be used to test hypotheses about specific functional forms. For example, if $\mu_{i k}=0$ for all $i$ and $k$ in Equation (2), this means that the production is homothetic, and output is separable from input prices. If $\mu_{\mathrm{ik}}=0$ for all $i$ and $k, \gamma_{i j}=0$ for all $i$ and $j$ and $\xi_{k r}=0$ for all $k$ and $r$, this implies that the elasticities of substitution between inputs are equal to 1 . In this case, the cost function corresponds to a Cobb-Douglas production function. The hypothesis of homotheticity is tested by imposing the restriction $\mu_{i k}=0$ on the cost function and performing a likelihood ratio

1 See Frank and Salkever (1994) for an analysis of nonprofit sector quality in the health sector. 
test. $^{12}$ The calculated Chi-square was 12.93 with 9 degrees of freedom. Therefore the hypothesis of homotheticity is not rejected. The calculated Chi-square under the hypothesis of Cobb-Douglas form was 109.57 with 21 degrees of freedom, leading to the rejection of the Cobb-Douglas functional form. The results below are based upon the general form depicted in Equation (2).

The estimated parameters of the short-run cost function are reported in Table 3. The first order parameters of prices and quantities $\left(\alpha_{1}, \alpha_{2}, \alpha_{3}, \pi_{1}, \pi_{2}, \pi_{3}\right)$ are positive and significant as suggested by theory, indicating that increases in production levels and the wage rates bring about increases in total variable cost. There exists a positive relation between total variable cost and quality. The first-order parameter of the quality index $\left(\tau_{1}\right)$ is positive and significant, which indicates, as expected, that an increase in quality is associated with an increase in total variable costs. The secondorder term of quality $\left(\tau_{2}\right)$ is not statistically different from zero. The coefficient demonstrates that if the quality index increases by $10 \%$, this brings a $4.0 \%$ increase in total variable costs. ${ }^{13}$ Research on child development used the same quality index and demonstrated the positive impact of process quality on children's language, pre-math skills, and social and cognitive development. The mean value of the quality index is 4.0, which represents mediocre quality. This means that the average center in our sample must increase its quality by 25 percent to achieve the level of quality considered "developmentally appropriate" by child care experts. Using the estimated coefficient of the quality index $\left(\tau_{1}\right)$, a $25 \%$ increase in quality implies a 10 percent increase in total

${ }^{12}$ The test statistic is $N\left[\ln \left|\Omega_{r}\right|-\ln \left|\Omega_{u}\right|\right]$, where $\Omega_{r}$ and $\Omega_{u}$ are the determinants of the residual variance-covariance matrix of the restricted and the unrestricted systems, respectively. It is distributed $\chi^{2}$ with degrees of freedom equal to the number of restrictions.

13 The interaction terms between quality and other variables drop out in evaluating the impact of a change in quality on TVC, if they are evaluated at the means. 
variable costs for the average center. The average total variable costs for centers is $\$ 225,406$. This implies that an increase the quality level of an average center to the level considered good by education experts would be associated with an additional cost of $\$ 22,540$ per year. Given that the average center provides a total of 137,228 hours of service to infant-toddlers, preschoolers and kindergarten-school age children in a year, it would cost an additional 16 cents per hour per child to produce good quality for an average center, keeping constant the space, the hours of service provided, and the wages paid to staff.

\section{Alternative functional forms for quality}

It should be noted that Equation (2) treats both quantity and quality as two attributes of output that are determined jointly. Thus, the model gives the centers the flexibility of increasing or decreasing the level of quality as a response to variation in wages. The cost function will include only in $\mathrm{q}$ and $\ln \mathrm{q}^{2}$, if one assumes that center quality is determined exogenously, or fixed in the short-run (This specification is used by Mocan 1995b). To investigate the results under this specification, quality is entered without the interaction terms. It is found that an increase of quality from average to good would cost an additional 13 cents per hour per child. Alternatively, a more flexible method of controlling for quality in this framework is to include a series of dummy variables. Inclusion of four dummy variables for quality intervals 0-2.5, 2.5-3.5, 4.5-5.5 and 5.5 and above (3.5-4.5 being the control group) revealed that centers that operate at the quality range of 4.5-5.5 have costs that are 7.5 percent higher than the ones that operate in the quality range of $3.5-4.5$, which is associated with an additional 12 cents per child per hour. Therefore these three alternative specifications generate a range of 12-16 cents per child per hour as the cost of increasing center quality from average to good. 


\section{The effect of center attributes}

Table 3 shows that the coefficient of the profit dummy $\left(\omega_{1}\right)$ is not significantly different from zero; neither is the coefficient of the dummy for national chains. The sum of the PROFTT and NATIONAL CHAIN coefficients were not significantly different from zero either. The model is also estimated by including the profit dummy only (i.e without NATIONAL CHAIN, PUBSUPP, PUBAUSP and SPECREG). The profit dummy was not significantly different from zero. The model reported in Table 3 is re-estimated by including interaction terms between PROFIT and state dummies. The results remained intact, suggesting that there are no efficiency differences between nonprofit centers and for-profit centers that are part of a national chain, and between nonprofit centers and non-chain for-profits. On the other hand, the coefficient of SPECREG $\left(\omega_{2}\right)$ is 0.18 , and significantly different from zero. This indicates that centers that receive public money, either from the state or federal government, that is tied to higher standards have variable costs that are 19 percent higher than their non-publicly owned or operated, or publicly supported nonprofit counterparts. ${ }^{14}$ SPECREG was robustly significant in all specifications, possibly reflecting expended and costly services in these centers.

\section{Comparison with previous research}

Previous research on efficiency differences between for-profit and nonprofit centers lacked a good proxy for center quality. As a result, researchers included the ratio of teaching staff to full-time equivalent children into cost equations as a control for quality (Powell \& Cosgrove 1992, Mukerjee \& Witte 1993, Preston 1993). This is problematic because the cost function already controls for the number of children served. Thus, including the ratio of teaching staff to children is analogous to adding the labor

\footnotetext{
14 Note that the percentage impact of the profit status on total variable cost is $\exp \left\{\omega_{2}-\right.$ $\left.1 / 2 \operatorname{Var}\left(\omega_{2}\right)\right\}-1$, where $\operatorname{Var}\left(\omega_{2}\right)$ is the variance of $\omega_{2}$ (Kennedy 1981).
} 
input (teaching staff) as an explanatory variable to the cost function. By the nature of the cost function, the amount of labor used is an endogenous variable, and should not be included as an independent variable into the cost function. Furthermore, even though the staff-child ratio is a determinant of center process quality, it captures only one dimension of center quality. In fact, there is evidence indicating that various structural quality indicators (e.g. staff-child ratio, group size, average education, experience and tenure of staff, etc.) explain only half of the variation in center process quality, and unobservable center characteristics are responsible for the remainder of the variation in quality across centers (Blau 1994; Mocan, Morris and Helburn 1995). This implies that staff-child ratio, included as a proxy for quality, would be measured with error. This may yield biased parameter estimates if the component of the process quality not explained by staffchild ratio is correlated with the right-hand side variables of the cost equation.

To investigate the sensitivity of the results to this measurement error and specification problem, a cost equation similar to the ones employed by previous studies (Powell and Cosgrove 1992) is estimated, where the staff-child ratio, the group size of children, center staff turnover, average education, experience and tenure of staff members, the percent children who are infants and age of the center are included as proxies for center quality. The variables are weighted by child-hours or by staff-hours, where appropriate. The descriptive statistics of these variables are reported in Table A-1 of the Appendix. The results are reported in Table 4. Although the main results remain the same, the coefficient of the profit dummy $\left(\omega_{1}\right)$ becomes negative and significant in agreement with Powell and Cosgrove (1992). According to Table 4, for-profit centers have 9 percent lower costs with respect to nonprofits, all else being equal. This result underscores the importance of controlling center quality carefully. Due to the unavailability of data, previous work relied on imprecise proxies of center quality, which resulted in biased estimates and inaccurate representation of production technology. 


\section{Sensitivity of the results to alternative specifications}

For centers that do not employ a particular group of workers, the state average wage is used. These centers, however, may react differently to marginal price changes than the firms which are at an interior optimum. ${ }^{\text {Is }}$ To investigate the sensitivity of the results, the cost function is estimated with centers that use all three types of labor. The results, which are reported in Table A-2 of the Appendix, are essentially the same as the ones reported in Table 3.

The cost function is estimated using the volunteer hours as a fixed instead of a variable input. This involved subtracting the value of in kind volunteer donations from total variable cost on the left-hand side of the equation and then including volunteer hours on the right-hand side. This can be justified if centers, in their long-range planning, can accurately forecast the number of volunteers hours to be received, and if they plan their operation by taking into account this factor. Using volunteer hours as a fixed input of production involves additional cross terms between volunteer hours, wages and outputs. The results (not reported in the interest of space) were very similar to the ones reported in Table 3. Similarly, treating directors as a fixed input, and subtracting their salaries from the total variable cost did not alter the results.

To control for possible endogeneity of wages paid to staff, a wage equation is estimated using 4,877 observations of workers where the logarithm of wages is regressed on age, age squared, education, experience, tenure, center characteristics such as PROF, SPECREG, PUBAUSP, PUBSUPP, NATIONAL CHAIN, and state dummies. The predicted wages are used to calculate the center weighted averages. Employing these new wage measures did not alter the results.

15 I thank David M. Blau for this insight. 


\section{Economies of scope and scale}

Economies of scope exists if there are complementarities between groups of outputs, and hence it is cheaper to produce them jointly than separately. Assume there are two categories of output: infant-toddlers, and older children. Following GyimahBrempong (1987), Murray and White (1983), Denny and Pinto (1978), economies of scope exists, if

(6) $\mathrm{C}\left(\mathrm{Y}_{1}, \mathrm{Y}_{2}\right)<\left\{\mathrm{C}\left(\mathrm{Y}_{1}, 0\right)+\mathrm{C}\left(0, \mathrm{Y}_{2}\right)\right\}$,

where $Y_{1}$ stands for the hours of service provided for infant-toddlers, and $Y_{2}$ is the hours of older children served. If the condition in (6) holds, the cost of serving infant-toddlers and older children jointly is less than the sum of the costs of serving them separately. In the long-run, a sufficient condition for the existence of scope economies between two outputs $i$ and $j$ is

(7) $C^{L R}{ }_{i j}=\partial^{2} C^{L R} / \partial Y_{i} \partial Y_{j}<0 \quad i \neq j$ for all $Y$, where $C^{L R}$ is the long-run cost function.

Equation (7) indicates that for long-run economies of scope to exist between outputs $Y_{i}$ and $Y_{j}$, an increase in $Y_{j}$ should decrease long-run marginal cost of $Y_{i}$. Note that

(8) $C^{L R}{ }_{i j}=\partial^{2} C^{L R} / \partial Y_{i} \partial Y_{j}=C^{S R}{ }_{i j}+C^{S R}\left(\partial K^{*} / \partial Y_{j}\right)$

where $\mathrm{C}^{\mathrm{SR}}{ }_{\mathrm{iK}}=\partial^{2} \mathrm{C}^{\mathrm{SR}} / \partial \mathrm{Y}_{\mathrm{i}} \partial \mathrm{K}, \mathrm{C}^{\mathrm{SR}}$ stands for the short-run cost function, and $\mathrm{K}^{*}$ is the longrun equilibrium value of $K$. If $K$ is normal, $\partial K^{*} / \partial Y_{j}>0$, and a sufficient condition for long-run scope economies is $\mathrm{C}^{\mathrm{SR}}{ }_{\mathrm{iK}}<0$ and $\mathrm{C}^{\mathrm{SR}}<0$.

In our context, if $\pi_{k} \pi_{r}+\xi_{k r}<0$ this implies that $C^{\text {SR }}{ }_{i j}<0$ (Vita 1990 , GyimahBrempong 1987, Murray and White 1983). The presence of scope economies is tested among infant-toddlers, preschoolers and kindergarten-school aged children by calculating $\pi_{k} \pi_{r}+\xi_{k r}$ for three possible combinations. Estimated $\pi_{1} \pi_{2}+\xi_{12}$ was 0.04174 with a 
standard error of $0.0206^{16}$ This means that the $95 \%$ confidence interval is $(0.001$. 0.082 ), indicating no economies of scope between infant-toddlers and preschoolers. The $95 \%$ confidence interval for $\pi_{1} \pi_{3}+\xi_{13}$ is $(0.006,0.039)$, which does not give support to the hypothesis of scope economies between infant-toddlers and school aged children. The 95\% confidence interval for scope economies between preschooler and school aged children is $(-0.032,0.024)$. Because it includes both the negative and positive regions, the inference is not conclusive, but nevertheless, the interval does not enable us to reject the hypothesis of no economies of scope. These results display no evidence indicating that serving various age groups jointly is more efficient than serving them separately

As Vita (1990) and Nelson (1985) outline, in the absence of the price of capital, long run scale economies (LSCE) can be calculated as

(9) $\quad \mathrm{LSCE}=(1-\partial \ln C / \partial \ln K) / \Sigma(\partial \ln C / \partial \ln \mathrm{Y})=$

$$
\begin{aligned}
& {\left[1-\left(\beta_{1}+\beta_{2} \ln K+\Sigma \delta_{i} \ln P_{i}+\Sigma \phi_{k} \ln K+\tau_{3} \operatorname{lnq}\right)\right] /} \\
& \left\{\Sigma \pi_{\mathrm{k}}+\Sigma \Sigma \xi_{\mathrm{kg}} \mathrm{Y}_{\mathrm{r}}+\Sigma \Sigma_{\mu} \ln \mathrm{P}_{\mathrm{i}}+\Sigma \phi_{\mathrm{k}} \ln \mathrm{L}+\Sigma \psi_{\mathrm{k}} \ln \mathrm{q}\right\} .
\end{aligned}
$$

When LSCE $>1$, there are scale economies. That is, a proportional increase in the hours of infant-toddlers, preschoolers and school aged children brings about a proportionately smaller increase in total variable cost. When LSCE $<1$, there are decreasing returns to scale, because an increase in the number of children served generates a proportionately larger increase in costs.

When mean-scaled data are used, the last four terms in the numerator and denominator of equation (9) are equal to zero. Therefore the measure of long-run scale economies reduces to $\mathrm{LSCE}=\left(1-\beta_{1}\right) / \Sigma \boldsymbol{\pi}_{\mathbf{k}}$.

The long-run scale economies obtained from Table 3 is 1.22 [(1-0.205) । $(0.26+0.30+0.09)]$, which reveals that a $10 \%$ increase in total hours of operation is associated with $8.2 \%$ increase in total variable costs for an average center in the long-

\footnotetext{
${ }^{16}$ The variance of $\pi_{1} \pi_{2}+\xi_{12}$ is equal to $\pi_{2}{ }^{2} \operatorname{Var}\left(\pi_{1}\right)+\pi_{1}{ }^{2} \operatorname{Var}\left(\pi_{2}\right)+\operatorname{Var}\left(\xi_{12}\right)$ $+2 \pi_{1} \pi_{2} \operatorname{Cov}\left(\pi_{1} \pi_{2}\right)+2 \pi_{2} \operatorname{Cov}\left(\pi_{1} \xi_{12}\right)+2 \pi_{1} \operatorname{Cov}\left(\pi_{2} \xi_{12}\right)$.
} 
run. The $95 \%$ confidence interval was $(1.02,1.41)$, which translates into 7.1 to 9.8 percent increase in costs following a $10 \%$ increase in output, demonstrating long-run scale economies.

There is significant variation in the length of full-time day across centers and among the age groups. Therefore, it is difficult to compare the number of full-timeequivalent children among centers. Given this caveat, the average center size is 67 fulltime-equivalent children. The economies of scale results indicate that an increase in this size would be associated with a decrease in average variable costs, keeping center quality constant.

\section{Labor-labor Substitution and Wage Elasticities of Labor Demand}

The Allen Elasticity of Substitution, $\sigma_{i j} i \neq j$, measures the effect on relative factor inputs of a change in the relative factor prices, holding constant output and other factor prices. Two factors are called $p$-complements ( $p$-substitutes), if $\sigma_{\mathrm{ij}}<0(>0)$. For our translog cost function, $\sigma_{i j}=\left(\gamma_{i j} / \alpha_{i} \alpha_{j}\right)+1 \quad i \neq j$.

The first panel of Table 5 presents the elasticities of substitution between three labor categories. The results indicate that centers can very easily substitute workers with 13-15 years of education for workers with 16 and more years of education. On the other hand, workers with 12 years or less of education and the ones with $16+$ years of education are complements in production. The same is true for workers with the least education and workers with 13 to 15 years of education. This result may imply that the least educated workers are supervised by workers with higher levels of education. This is an interesting result and it underlines the importance of classifying labor by education. The classification of labor by title (e.g. teachers, teacher aides, etc.) may not be reliable, because the skill embodied in each group categorized by title may differ greatly across centers. This is because the designation of titles may be arbitrary (a teacher at one center may have the title of assistant teacher at another center). The classification of labor by education, on the other hand, creates more homogeneous categories of labor and 
generates a more lucid picture of substitution elasticities. ${ }^{17}$

The differences in the elasticities of substitution across three labor categories suggests that these inputs are not separable. Separability among inputs is equivalent to having the marginal rates of substitution in each separated group be independent of the amount of factors outside the group (Hamermesh and Grant 1979). For example, separability of labor inputs $L_{1}$ and $L_{2}$ from the third category of labor $L_{3}$, means that $\ln \mathrm{Y}=f\left(g\left(\ln \mathrm{L}_{1}, \ln \mathrm{L}_{2}\right), \ln \mathrm{L}_{3}\right)$, where $\mathrm{Y}$ stands for output. A sufficient condition for separability in this case is $\sigma_{13}=\sigma_{23}$, which implies $\alpha_{1}=\alpha_{2} \gamma_{13} / \gamma_{23}$ (Hamermesh and Grant 1979, Denny and Fuss 1977). Separability among inputs is formally tested by imposing the condition above and performing a likelihood ratio test. The likelihood ratio statistic with one degree of freedom was 7.82 for separability of $L_{1}$ and $L_{2}$ from $L_{3}$. It was 5.85 for separability of $L_{1}$ and $L_{3}$ from $L_{2}$, and 0.90 for separability of $L_{2}$ and $L_{3}$ from $L_{1}$, where $L_{1}$ stands for workers with 12 years or less education, $L_{2}$ stands for workers with 13-15 years of education, and $L_{3}$ is workers with $16+$ years of education. Thus, workers with 12 or less years of schooling and the ones with 13 to 15 years of schooling are not separable from workers with 16 and more years of education. Similarly, workers with the least education and with highest education are not separable from the group with 13-15 years of education. On the other hand, workers with 13-15 years of education and workers with $16+$ years of education are separable from the ones with 12 and less years of education. This suggests that disaggregating labor by title will lead to incorrect inferences about the elasticities of substitution, if there is overlap in distribution of education among categories.

The second panel of Table 5 reports the estimated constant-output (short-run) labor demand elasticity $(\eta)$ for three labor categories. It can be shown that $\eta_{i}=\left(\gamma_{\mathrm{ii}}+\alpha_{\mathrm{i}}^{2}-\alpha_{\mathrm{i}}\right) / \alpha_{\mathrm{i}}$,

17 For example Powell and Cosgrove (1992) found that teachers and aides are substitutes to each other, although their cost function included a third input (using their Table 2). 
where $\alpha_{i}$ is the estimated share of the ith input in total variable cost. The estimated own price elasticity for workers with less than 12 years of education is positive which is contradictory to economic theory. This result, however, is due to the large second order coefficient $\gamma_{11}$. The variance of the elasticity is calculated, which is then used to test the hypothesis that the elasticity is equal to zero. The variance of $\eta_{1}$ is equal to

$$
\left(1 / \alpha_{1}\right)^{2} \operatorname{Var}\left(\gamma_{11}\right)+\left[1-\left(\gamma_{11} / \alpha_{1}^{2}\right)\right]^{2} \operatorname{Var}\left(\alpha_{1}\right)+2 \operatorname{Cov}\left(\gamma_{11}, \alpha_{1}\right)\left(1 / \alpha_{1}\right)\left[1-\left(\gamma_{11} / \alpha_{1}^{2}\right)\right]
$$

The calculated t-statistic under the null hypothesis of perfectly inelastic labor demand for workers with education less than 12 years is 0.53 . Thus, we could not reject the hypothesis that labor demand for these workers is perfectly inelastic in the short-run. This means that in the short-run, centers would not reduce their demand for these workers in the face of a wage increase. This result is intuitive because given that the level of operation is constant in the short-run, centers may not have much flexibility in terms of reducing the labor usage, if state-mandated staff-child ratio requirements are binding. For a given number of children, centers have to einploy a minimum number of adults (teachers and aides) dictated by state regulations. Thus, small increases in the wages paid to low educated workers will not generate a reduction in center's demand for these workers as long as the increase in the wage rate is not large enough to exceed the level paid to those workers with higher education. The demand elasticity for workers with 13-15 years of education is -0.44 , and the one for worker with $16+$ years of education is -0.33 , indicating that centers do not have much flexibility in the short-run to adjust their labor usage in the presence of wage increases. ${ }^{18}$

18 As Hamermesh and Grant (1979) indicate, estimation of own-price elasticities may be biased towards zero in the absence of capital, because the substitution toward capital following a wage increase is not accounted for. However, as described earlier, capital in this industry is the physical plant, which is difficult to expand or contract, at least in the short-run. Similarty, the state-mandated staff-child ratios make it difficult to switch to a more capital intensive technology following an increase in the wage rates. Because 


\section{Conclusion}

Research in child development has demonstrated a direct association between the quality of child care and children's social and cognitive developments, and academic achievements (Ramey and Campbell 1991). Similarly, the links between academic achievements and labor market success, and cognitive skills and wages have been documented in the economics literature (Murnane, Willett and Levy 1995). The growing wage inequality in the United States, and the relationship between quality of child care, cognitive skills and labor market success make it crucial to investigate the way the child care industry functions. The issue is important, especially because the average quality of center-based child care provided in the United States is below the level that is considered good by professionals in early child care and education (Whitebook et al., 1990), and because the demand for child care is increasing rapidly.

There exists a strong folklore in the child care industry as to the behavior of for-profit and nonprofit centers along these lines. Nonprofit centers are accused of "shirking"; i.e. producing child care services at higher costs than their for-profit counterparts. For-profit centers, on the other hand, are being blamed for "cheating "; i.e. producing lower quality, and therefore taking advantage of the consumers who cannot have perfect information about the quality of services purchased. Anecdotal and some scattered empirical evidence are cited to support both of these positions. However, there has been only a few economic studies to shed light on these claims, and they suffer from various data limitations. Similarly, in many cases data limitations prevented previous

${ }^{18}$ (...continued)

of these reasons, the reported wage elasticities can be regarded as accurate. The inclusion of the price of capital has its own problems. If the measurement error in the price of capital is larger than that of the wage rates, the inclusion of the price of capital may create more harm than good, because the elasticities of substitution and the price elasticities can be very sensitive to the noise in the price of capital (Berndt 1976, Hamermesh and Grant 1979). 
research from providing credible information on production technology, elasticities of substitution and economies of scope in the industry.

This paper uses a new data set which is constructed through visits to child care centers and which contains extraordinary detail on center characteristics, workers and children. Quality is measured by an index, which has been widely used in child development literature, and which has been shown to be positively related to child outcomes.

The paper provides a number of important insights into the characteristics of the child care industry. First, there is no difference in average quality of the services produced between nonprofit and for-profit centers. This result is important because it demonstrates that on the average, the hypothesis of for-profit centers taking advantage of the information asymmetry on quality is incorrect, and indicates that nonprofit status cannot be taken as a signal of higher quality.

The results also show that the hypothesis of relative inefficiency of nonprofit centers (the shirking hypothesis) is unfounded. Estimation of translog cost functions reveal that there is no efficiency difference between for-profit and nonprofit centers in terms of producing child care services, keeping quality constant. However, if center quality is approximated by inaccurate measures, such as staff-child ratios, erroneous results emerge as to the relative efficiency of the two sectors. Centers associated with one segment of the nonprofit sector (centers that receive public money, either from the state or federal government, that is tied to higher standards) have variable costs that are 19 percent higher than their non-publicly owned or operated, or publicly supported nonprofit counterparts.

Classification of labor into three categories by education reveals that the labor sub-categories should not be combined into one group, and doing so may lead to incorrect inferences about the substitution possibility among inputs. Child care workers with 13 to 15 years of education and workers with 16 and more years of education are substitutes. On the other hand, both of these groups are complements to workers with 
12 and less years of education. Centers have inelastic demand for workers.

There are economies of scale in production. Controlling for the level of quality of services, a 10 percent increase in hours of children served brings about only an 8.5 percent increase in costs in the long-run. There is no evidence of economies of scope. Serving various age groups jointly is not more efficient than serving them separately, although the issue is less clear in the case of preschoolers and school age children.

Estimation results show that the cost of increasing the quality of an average center from mediocre to good is between 12-16 cents per child-hour. 
Table 1

Descriptive Statistics

\begin{tabular}{|c|c|c|c|c|}
\hline Variable & Definition & $\begin{array}{c}\text { Profit } \\
(N=200)\end{array}$ & $\begin{array}{c}\text { Non- } \\
\text { Profit } \\
(\mathrm{N}=196)\end{array}$ & $\begin{array}{c}\text { All } \\
(N=396)\end{array}$ \\
\hline TVC & $\begin{array}{l}\text { Total Variable Cost (The sum of } \\
\text { wage and salary expenditures, } \\
\text { nonwage benefits, staff education } \\
\text { costs, subcontracting costs, food } \\
\text { costs, other operating expenses, and } \\
\text { the estimated value of in kind } \\
\text { donations and owner-director } \\
\text { salaries). }\end{array}$ & $\begin{array}{c}218,953 \\
(138,035)\end{array}$ & $\begin{array}{c}231,990 \\
(171,826)\end{array}$ & $\begin{array}{l}225,406 \\
(155,618)\end{array}$ \\
\hline WAGE1 & $\begin{array}{l}\text { Center weightod average wages for } \\
\text { staff with } 12 \text { years or less formal } \\
\text { education ( } \$ \text { /hour). }\end{array}$ & $\begin{array}{l}5.64 \\
(1.13)\end{array}$ & $\begin{array}{l}5.86 \\
(1.30)\end{array}$ & $\begin{array}{l}5.75 \\
(1.22)\end{array}$ \\
\hline WAGE2 & $\begin{array}{l}\text { Center weighted average wages for } \\
\text { staff with 13-15 years of education } \\
\text { (\$/hour). }\end{array}$ & $\begin{array}{l}6.26^{\circ} \\
(1.41)\end{array}$ & $\begin{array}{l}6.83^{\circ} \\
(1.96)\end{array}$ & $\begin{array}{l}6.54 \\
(1.72)\end{array}$ \\
\hline WAGE3 & $\begin{array}{l}\text { Center weighted average wages for } \\
\text { staff with } 16 \text { and more years of } \\
\text { education ( } \$ \text { hour). }\end{array}$ & $\begin{array}{l}6.95^{\circ} \\
(1.65)\end{array}$ & $\begin{array}{l}8.11^{\circ} \\
(2.83)\end{array}$ & $\begin{array}{l}7.53 \\
(2.38)\end{array}$ \\
\hline $\begin{array}{l}\text { INFANT- } \\
\text { TODDLER }\end{array}$ & $\begin{array}{l}\text { Total annual hours of service the } \\
\text { center provided for infant-toddlers } \\
\text { in fiscal year. }\end{array}$ & $\begin{array}{r}34,877^{\circ} \\
(32,814)\end{array}$ & $\begin{array}{c}23,827^{*} \\
(39,237)\end{array}$ & $\begin{array}{c}29,408 \\
(36,511)\end{array}$ \\
\hline PRESCHOOL & $\begin{array}{l}\text { The annual hours of service } \\
\text { provided for preschoolers. }\end{array}$ & $\begin{array}{c}92,031 \\
(75.534)\end{array}$ & $\begin{array}{l}88,303 \\
(70,377)\end{array}$ & $\begin{array}{c}90,186 \\
(72,959)\end{array}$ \\
\hline SCHOOLAGE & $\begin{array}{l}\text { The annual hours of care provided } \\
\text { for kindergarten-school age } \\
\text { children. }\end{array}$ & $\begin{array}{r}22.453^{\circ} \\
(33.430)\end{array}$ & $\begin{array}{l}12.718^{\circ} \\
(20.221)\end{array}$ & $\begin{array}{c}17,635 \\
(28,083)\end{array}$ \\
\hline
\end{tabular}




\begin{tabular}{|c|c|c|c|c|}
\hline \multicolumn{5}{|c|}{ (Table 1 concluded) } \\
\hline PROFIT & $\begin{array}{l}\text { Dummy variable }(=1) \text { if the center } \\
\text { is for-profit, }(=0) \text { otherwise. }\end{array}$ & --- & -- & $\begin{array}{l}0.505 \\
(0.501)\end{array}$ \\
\hline $\begin{array}{l}\text { NATIONAL } \\
\text { CHAIN }\end{array}$ & $\begin{array}{l}\text { Dummy variable }(=1) \text { if the ceater } \\
\text { is a part of a for-profit mational } \\
\text { chain, }(=0) \text { otherwise. }\end{array}$ & $\begin{array}{l}0.240 \\
(0.428)\end{array}$ & $\cdots$ & $\begin{array}{l}0.121 \\
(0.327)\end{array}$ \\
\hline SPECREG & $\begin{array}{l}\text { Dummy variable }(=1) \text { if the center } \\
\text { receives public money, }(=0) \\
\text { otherwise. }\end{array}$ &.-- & $\begin{array}{l}0.143 \\
(0.351)\end{array}$ & $\begin{array}{c}0.071 \\
(0.257)\end{array}$ \\
\hline PUBAUSP & $\begin{array}{l}\text { Dummy variable }(=1) \text { if the center } \\
\text { is owned and operated by public } \\
\text { agencies, }(=0) \text { otherwise. }\end{array}$ & $\ldots$ & $\begin{array}{l}0.138 \\
(0.346)\end{array}$ & $\begin{array}{l}0.068 \\
(0.252)\end{array}$ \\
\hline PUBSUPP & $\begin{array}{l}\text { Dummy variable }(=1) \text { if the center } \\
\text { is not publicly owned or operated, } \\
\text { but receives more than } 50 \text { percent of } \\
\text { its revenue from public grants, fees } \\
\text { and USDA reimbursement, }(=0) \\
\text { otherwise. }\end{array}$ & $\begin{array}{l}0.040 \\
(0.196)\end{array}$ & $\begin{array}{l}0.194 \\
(0.396)\end{array}$ & $\begin{array}{l}0.116 \\
(0.321)\end{array}$ \\
\hline SPACE & $\begin{array}{l}\text { The square footage of the inside } \\
\text { space used by children. }\end{array}$ & $\begin{array}{l}4,703 \\
(3,383)\end{array}$ & $\begin{array}{c}5,098 \\
(4,687)\end{array}$ & $\begin{array}{c}4,898 \\
(4,081)\end{array}$ \\
\hline QUALITY & $\begin{array}{l}\text { The average classroom process } \\
\text { quality, weighed by enroliments at } \\
\text { the appropriate age levels. }\end{array}$ & $\begin{array}{c}3.87^{*} \\
(0.85)\end{array}$ & $\begin{array}{l}4.15^{\prime} \\
(0.83)\end{array}$ & $\begin{array}{l}4.01 \\
(0.85)\end{array}$ \\
\hline
\end{tabular}

The numbers in each cell are the means. The values in parenthesis are the standard deviations. $\left({ }^{*}\right)$ indicates that the means between for-profit and nonprofit centers are different at the $5 \%$ level. 
Table 2

Descriptive Statistics by State and Profit Status

\begin{tabular}{|c|c|c|c|c|c|}
\hline Variable & $\begin{array}{l}\text { Center } \\
\text { Type }\end{array}$ & California & Colorado & Connecticut & $\begin{array}{l}\text { North } \\
\text { Carolina }\end{array}$ \\
\hline \multirow{2}{*}{ TVC } & For-profit & $\begin{array}{c}273,582 \\
(201,970)\end{array}$ & $\begin{array}{l}215,675 \\
(93,158)\end{array}$ & $\begin{array}{c}202,748 \\
(112,664)\end{array}$ & $\begin{array}{c}185,226 \\
(106,593)\end{array}$ \\
\hline & Nonprofit & $\begin{array}{c}240,389 \\
(163,689)\end{array}$ & $\begin{array}{c}207,029 \\
(157,781)\end{array}$ & $\begin{array}{c}250,433 \\
(160,526)\end{array}$ & $\begin{array}{c}230,800 \\
(204,329)\end{array}$ \\
\hline \multirow[t]{2}{*}{ QUALITY } & For-profit & $\begin{array}{l}4.15 \\
(0.75)\end{array}$ & $\begin{array}{c}3.80 \\
(0.61)\end{array}$ & $\begin{array}{c}4.35 \\
(0.83)\end{array}$ & $\begin{array}{l}3.18^{*} \\
(0.72)\end{array}$ \\
\hline & Nonprofit & $\begin{array}{c}4.35 \\
(0.87)\end{array}$ & $\begin{array}{c}3.93 \\
(0.77)\end{array}$ & $\begin{array}{c}4.32 \\
(0.82)\end{array}$ & $\begin{array}{l}3.98^{\circ} \\
(0.79)\end{array}$ \\
\hline \multirow[t]{2}{*}{ WAGEl } & For-profit & $\begin{array}{c}6.25 \\
(1.38)\end{array}$ & $\begin{array}{l}4.93^{*} \\
(0.55)\end{array}$ & $\begin{array}{c}6.38 \\
(0.94)\end{array}$ & $\begin{array}{l}5.01 \\
(0.56)\end{array}$ \\
\hline & Nonprofit & $\begin{array}{c}6.27 \\
(1.46)\end{array}$ & $\begin{array}{l}5.26^{*} \\
(0.98)\end{array}$ & $\begin{array}{c}6.75 \\
(1.24)\end{array}$ & $\begin{array}{l}5.17 \\
(0.65)\end{array}$ \\
\hline \multirow[t]{2}{*}{ WAGE2 } & For-profit & $\begin{array}{c}7.58 \\
(1.85)\end{array}$ & $\begin{array}{l}5.40^{\circ} \\
(0.49)\end{array}$ & $\begin{array}{c}6.88^{\circ} \\
(1.03)\end{array}$ & $\begin{array}{l}5.19^{\circ} \\
(0.47)\end{array}$ \\
\hline & Nomprofit & $\begin{array}{c}7.81 \\
(2.17)\end{array}$ & $\begin{array}{l}6.11^{\circ} \\
(1.41)\end{array}$ & $\begin{array}{l}7.85^{\circ} \\
(1.96)\end{array}$ & $\begin{array}{c}5.53^{\circ} \\
(0.84)\end{array}$ \\
\hline \multirow[t]{3}{*}{ WAGE3 } & For-profit & $\begin{array}{l}8.37^{*} \\
(1.47)\end{array}$ & $\begin{array}{l}5.87^{*} \\
(0.90)\end{array}$ & $\begin{array}{l}7.84^{*} \\
(1.52)\end{array}$ & $\begin{array}{l}5.74^{*} \\
(0.54)\end{array}$ \\
\hline & Nonprofit & $\begin{array}{c}9.56^{*} \\
(2.66)\end{array}$ & $\begin{array}{c}6.76^{\circ} \\
(1.74)\end{array}$ & $\begin{array}{c}9.89^{*} \\
(3.21)\end{array}$ & $\begin{array}{c}6.24^{\circ} \\
(1.16)\end{array}$ \\
\hline & & $\begin{array}{l}N(\text { for }-p r)=49 \\
N(\text { nonpr) }=50\end{array}$ & $\begin{array}{l}N(\text { for }-p r)=50 \\
N(\text { nompr })=50\end{array}$ & $\begin{array}{l}N(\text { for-pr) }=51 \\
N(\text { nonpr })=48\end{array}$ & $\begin{array}{l}N(\text { for-pr) }=50 \\
N(\text { nonpr) }=48\end{array}$ \\
\hline
\end{tabular}

a: The first number in each cell is the mean. The number in the parenthesis is the standard deviation. (*) indicates that the corresponding means between for-profit and nonprofit centers are significantly different from each other. 
Table 3

Short-run Translog Cost Function Regression ${ }^{2}$

\begin{tabular}{|c|c|c|c|}
\hline $\begin{array}{c}\text { Variable Name } \\
\text { I }\end{array}$ & $\begin{array}{c}\text { Parameter } \\
\text { II }\end{array}$ & $\begin{array}{c}\text { Coefficient } \\
\text { III }\end{array}$ & $\begin{array}{c}\text { t-Statistic } \\
\text { IV }\end{array}$ \\
\hline Constant & $\alpha_{0}$ & $12.486^{\circ}$ & 256.628 \\
\hline Wagel & $\alpha_{1}$ & $0.221^{\circ}$ & 17.190 \\
\hline Wage2 & $\alpha_{2}$ & $0.371^{*}$ & 22.700 \\
\hline Wage3 & $\alpha_{\mathbf{3}}$ & $0.221^{\circ}$ & 15.940 \\
\hline Infant-toddler & $\pi_{1}$ & $0.263^{*}$ & 8.981 \\
\hline Preschool & $\pi_{1}$ & $0.298^{*}$ & 7.045 \\
\hline Schoolage & $\pi_{3}$ & $0.095^{\circ}$ & 4.188 \\
\hline Infant Preschool & $\xi_{12}$ & $-0.037^{\circ}$ & -2.849 \\
\hline Infant * Schoolage & $E_{13}$ & -0.002 & -0.956 \\
\hline Preschool * Schoolage & $\xi_{20}$ & $-0.032^{\circ}$ & -2.948 \\
\hline Infant-toddler ${ }^{2}$ & $\xi_{1:}$ & $0.082^{\prime}$ & 5.555 \\
\hline Preschool $^{2}$ & $\xi_{n}$ & $0.147^{\circ}$ & 4.460 \\
\hline Schoolage ${ }^{2}$ & $\xi_{33}$ & $0.032^{\circ}$ & 3.210 \\
\hline Wagel $^{2}$ & $\gamma_{11}$ & $0.202^{\circ}$ & 3.639 \\
\hline Wage2 $^{2}$ & $\gamma_{22}$ & 0.069 & 0.865 \\
\hline Wage $^{2}$ & $\gamma_{\mathbf{y}}$ & $0.102^{\circ}$ & 1.960 \\
\hline Wagel * Wage2 & $\mathbf{\gamma}_{12}$ & -0.092 & -1.742 \\
\hline
\end{tabular}




\begin{tabular}{|c|c|c|c|}
\hline \multicolumn{4}{|c|}{ (Table 3 continued) } \\
\hline Wage1 * Wage3 & $\gamma_{13}$ & $-0.110^{\circ}$ & -2.915 \\
\hline Wage2 * Wage3 & $\gamma_{23}$ & 0.083 & 1.571 \\
\hline Space & $\beta_{1}$ & 0.205 & 4.687 \\
\hline Space ${ }^{2}$ & $\boldsymbol{B}_{2}$ & -0.007 & -0.147 \\
\hline Wagel * Space & $\delta_{1}$ & 0.010 & 0.747 \\
\hline Wage2 * Space & $\delta_{2}$ & -0.013 & -0.698 \\
\hline Wage $3 *$ Space & $\delta_{3}$ & 0.017 & 1.106 \\
\hline Wagel * Infant-toddler & $\mu_{11}$ & $0.015^{\circ}$ & 3.090 \\
\hline Wagel * Preschool & $\mu_{12}$ & -0.015 & -1.385 \\
\hline Wagel * Schoolage & $\mu_{33}$ & -0.001 & -0.145 \\
\hline Wage2 * Infant-toddler & $\mu_{21}$ & -0.007 & -1.406 \\
\hline Wage2 * Preschool & $\mu_{22}$ & 0.022 & 1.633 \\
\hline Wage2 * Schoolage & $\mu_{23}$ & -0.004 & -0.902 \\
\hline Wage $3 *$ Infant-toddler & $\mu_{31}$ & -0.006 & -1.346 \\
\hline Wage3 * Preschool & $\mu_{32}$ & -0.007 & -0.645 \\
\hline Wage3 * Schoolage & $\mu_{33}$ & 0.002 & 0.470 \\
\hline Space * Infant-toddler & $\Phi_{1}$ & 0.002 & 0.171 \\
\hline Space * Preschool & $\Phi_{2}$ & $-0.087^{\circ}$ & -2.534 \\
\hline Space * Schoolage & $\Phi_{3}$ & 0.017 & 1.528 \\
\hline
\end{tabular}




\begin{tabular}{|c|c|c|c|}
\hline \multicolumn{4}{|c|}{ (Table 3 concluded) } \\
\hline Quality & $r_{1}$ & $0.400^{\circ}$ & 3.584 \\
\hline Quality $^{2}$ & $r_{2}$ & 0.616 & 1.444 \\
\hline Quality * Space & $r_{3}$ & -0.007 & -0.067 \\
\hline Quality * Wage1 & $\mathbf{a}_{\mathbf{1}}$ & $-0.212^{\circ}$ & -5.237 \\
\hline Quality * Wage2 & $\mathbf{a}_{2}$ & 0.035 & 0.677 \\
\hline Quality * Wage3 & $\mathbf{a}_{3}$ & $0.228^{\circ}$ & 5.192 \\
\hline Quality * Infant-toddler & $\psi_{1}$ & 0.011 & 0.377 \\
\hline Quality * Preschool & $\psi_{2}$ & 0.028 & 0.386 \\
\hline Quality * Schoolage & $\psi_{3}$ & -0.022 & -0.756 \\
\hline Profit & $w_{1}$ & -0.041 & -1.198 \\
\hline Specreg & $w_{2}$ & $0.181^{*}$ & 2.810 \\
\hline Pubsupp & $\omega_{3}$ & 0.081 & 1.576 \\
\hline Public Auspice & $\omega_{4}$ & 0.036 & 0.585 \\
\hline National Chain & $w_{s}$ & -0.021 & -0.407 \\
\hline California & $\omega_{6}$ & $-0.197^{\circ}$ & -4.496 \\
\hline Colorado & $\omega_{7}$ & $-0.130^{*}$ & -3.085 \\
\hline North Carolina & $\omega_{\mathbf{k}}$ & $-0.298^{*}$ & -6.426 \\
\hline Box-Cox Parameter & $\lambda$ & 0.206 & 4.196 \\
\hline
\end{tabular}

* Statistically significant at the 5 percent level. $\mathrm{N}=396$. 
Table 4

Translog Short-run Cost Functions with Structural Quality*

\begin{tabular}{|c|c|c|c|}
\hline $\begin{array}{c}\text { Variable } \\
\text { I }\end{array}$ & $\begin{array}{c}\text { Parameter } \\
\text { II }\end{array}$ & $\begin{array}{c}\text { Coefficient } \\
\text { III }\end{array}$ & $\begin{array}{c}\text { t-Statistic } \\
\text { IV }\end{array}$ \\
\hline Constant & $\alpha_{0}$ & $12.737^{\circ}$ & 146.441 \\
\hline Wagel & $\alpha_{1}$ & $0.210^{\circ}$ & 21.173 \\
\hline Wage2 & $\alpha_{2}$ & $0.381^{\circ}$ & 31.296 \\
\hline Wage3 & $\alpha_{3}$ & $0.225^{\circ}$ & 20.364 \\
\hline Infant-toddler & $\pi_{1}$ & $0.219^{\circ}$ & 5.929 \\
\hline Preschool & $\pi_{2}$ & $0.364^{\circ}$ & 7.871 \\
\hline Schoolage & $\pi_{3}$ & $0.090^{\circ}$ & 4.896 \\
\hline Infant * Preschool & $\xi_{12}$ & $-0.118^{\circ}$ & -4.102 \\
\hline Infant * Schoolage & $\xi_{13}$ & -0.007 & -0.706 \\
\hline Preschool Schoolage & $\xi_{2}$ & $-0.064^{\circ}$ & -3.916 \\
\hline Infant-toddler ${ }^{2}$ & $\xi_{11}$ & 0.003 & 0.127 \\
\hline Preschool $^{2}$ & $\xi_{22}$ & -0.077 & -1.568 \\
\hline Schoolage 2 & $\xi_{33}$ & -0.005 & -0.610 \\
\hline Wagel $^{2}$ & $\boldsymbol{\gamma}_{11}$ & $0.218^{\circ}$ & 3.932 \\
\hline Wage ${ }^{2}$ & $\gamma_{22}$ & 0.109 & 1.329 \\
\hline Wage $3^{2}$ & $\gamma_{33}$ & $0.116^{\circ}$ & 2.288 \\
\hline Wagel * Wage2 & $\gamma_{12}$ & $-0.112^{\circ}$ & -2.068 \\
\hline
\end{tabular}




\begin{tabular}{|c|c|c|c|}
\hline \multicolumn{4}{|c|}{ (Table 4 continued) } \\
\hline Wagel * Wage3 & $\gamma_{13}$ & $-0.108^{\prime}$ & -2.902 \\
\hline Wage2 * Wage3 & $\gamma_{\boldsymbol{z}}$ & 0.083 & 1.571 \\
\hline Space & $\beta_{1}$ & $0.243^{\circ}$ & 6.679 \\
\hline Space ${ }^{2}$ & $\boldsymbol{\beta}_{2}$ & -0.023 & -0.897 \\
\hline Wagel * Space & $\delta_{1}$ & 0.010 & 0.607 \\
\hline Wage2 * Space & $\delta_{2}$ & -0.030 & -1.533 \\
\hline Wage3 * Space & $\delta_{3}$ & 0.033 & 1.851 \\
\hline Wagel $*$ Infant-toddler & $\mu_{n}$ & $0.041^{\circ}$ & 4.929 \\
\hline Wagel * Preschool & $\mu_{12}$ & -0.023 & -1.564 \\
\hline Wagel * Schoolage & $\mu_{13}$ & 0.001 & 0.123 \\
\hline Wage2 * Infant-toddler & $\mu_{21}$ & -0.013 & -1.217 \\
\hline Wage2 * Preschool & $\mu_{n}$ & $0.052^{\circ}$ & 2.793 \\
\hline Wage2 * Schoolage & $\mu_{23}$ & -0.006 & -0.682 \\
\hline Wage3 * Infant-toddler & $\mu_{3_{1}}$ & $-0.023^{\circ}$ & -2.573 \\
\hline Wage3 * Preschool & $\mu_{32}$ & -0.027 & -1.611 \\
\hline Wage3 * Schoolage & $\mu_{33}$ & -0.002 & -0.251 \\
\hline Space * Infant-toddler & $\Phi$ & 0.044 & 1.648 \\
\hline Space * Preschool & $\Phi_{2}$ & -0.031 & -0.662 \\
\hline Space * Schoolage & $\Phi_{3}$ & 0.041 & 1.756 \\
\hline
\end{tabular}




\begin{tabular}{|c|c|c|c|}
\hline \multicolumn{4}{|c|}{ (Table 4 concluded) } \\
\hline Suff-Child Ratio & & 0.025 & 1.166 \\
\hline Group Size & & -0.041 & -1.479 \\
\hline Tumover & & -0.008 & -0.625 \\
\hline Education & & $-0.100^{\circ}$ & -5.697 \\
\hline Experience & & -0.035 & -1.742 \\
\hline Tenure & & -0.034 & -1.536 \\
\hline$\%$ Infants & & 0.004 & 0.112 \\
\hline Center Age & & 0.010 & 0.542 \\
\hline Profit & $\omega_{1}$ & $-0.092^{*}$ & -2.639 \\
\hline Specreg & $\omega_{2}$ & $0.271^{\circ}$ & 3.985 \\
\hline Pubsupp & $\omega_{3}$ & 0.033 & 0.630 \\
\hline Public Auspice & $\omega_{4}$ & 0.094 & 1.530 \\
\hline National Chain & $\omega_{s}$ & -0.020 & -0.387 \\
\hline California & $\omega_{6}$ & $-0.174^{\circ}$ & -3.930 \\
\hline Colorzdo & w & $-0.163^{\circ}$ & -3.749 \\
\hline North Carolina & $\omega_{4}$ & $-0.357^{\circ}$ & -7.714 \\
\hline Box-Cox Parameter & $\lambda$ & $0.703^{\circ}$ & 10.263 \\
\hline
\end{tabular}

* Statistically significant at the 5 percent level. $\mathrm{N}=384$. 
Table 5

Substitution and Labor Demand Elasticities

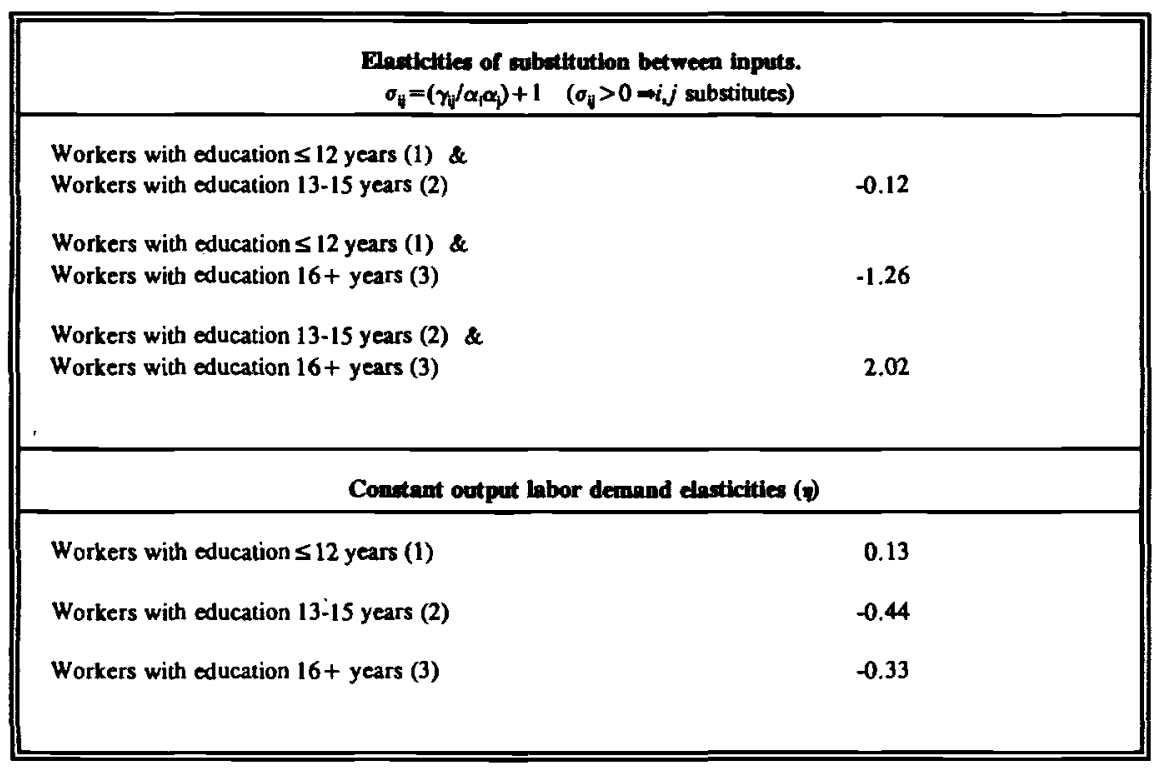




\section{REFERENCES}

Angrist, Joshua D. and Alan B. Krueger, 1991, "Does Compulsory School Attendance Affect Schooling and Earnings?" Quarterly Journal of Economics, 106:4, pp. 9791014

Arnett, Joyce, 1989, "Caregivers in Day-Care Centers: Does Training Matter?" Journal of Applied Developmental Psychology, 10, pp.541-552.

Berndt, Ernst, 1976, "Reconciling Alternative Estimates of the Elasticity of Substitution," Review of Economics and Statistics, pp.59-68.

Betancourt, Roger and John Edwards, 1987, "Economies of Scale and the Load Factor in Electricity Generation," Review of Economics and Statistics, pp. 551-56.

Blau, David M., 1994, "The Production of Quality in Child Care Centers," mimeo, University of North Carolina at Chapel Hill.

Blau, David M., 1993, "The Supply of Child Care Labor," Journal of Labor Economics, $11: 2$, pp. 324-47.

Blau, David M., and V. Joseph Hotz, 1992, "Introduction to the Special Issue on Child Care," Journal of Human Resources, 27:1 pp. 1-8.

Blau, David M., 1992, "The Child Care Labor Market, " Journal of Human Resources, 27:1 pp. 9-39.

Blau, David M., 1991, "The Quality of Child Care: An Economic Perspective," in The Economics of Child Care, David M. Blau (ed.), Russell Sage Foundation: New York.

Blau, David M. and Philip K. Robins, 1988, "Child Care Costs and Family Labor Supply," The Review of Economics and Statistics, 70: 374-81.

Burtless, Gary, "Earnings Inequality over the Business and Demographic Cycles," in Gary Burtless (ed.), A Future of Lousy Jobs? The Changing Structure of U.S. Wages, Washington, D.C. Brookings Institution, 1990, pp. 7-117.

Callan, Scott J. and Rexford E. Santerre, 1990, "The Production Characteristics of Local Public Education: A Multiple Product and Input Analysis, "Southern Economic Journal, 57:2, pp.468-80.

Caves, Douglas W., and Laurits R. Christensen, 1980, "The Global Properties of Flexible Functional Forms," The American Economic Review, pp. 422-32.

Caves, Douglas W., Laurits R. Christensen and Michael W. Tretheway, "Flexible Cost Functions for Multiproduct Firms," 1980, The Review of Economics and Statistics, pp. 477-81 
Christensen, Laurits, Dale Jorgensen, and Lawrence Lau 1973, "Transcendental Logarithmic Production Frontiers," Review of Economics and Statistics, pp. 28-45.

Coleman, Mary T., 1993, "Movements in the Earnings-Schooling Relationship," Journal of Human Resources, 28:3, pp. 660-80.

Cowing, Thomas G. and Alphonse G. Holtmann, 1983, "Multiproduct Short-Run Hospital Cost Functions: Empirical Evidence and Policy Implications from CrossSection Data," Southern Economic Journal, pp. 637-53.

Cutler, David M. and Lawrence F. Katz, 1991, "Macroeconomic Performance and the Disadvantaged," Brookings Papers on Economic Activity, pp.1-61.

Denny, Michael, and Cheryl Pinto, 1978, "An Aggregate Model with Multi-product Technologies," in Production Economics: A Dual Approach to Theory and Applications; M.Fuss and D. McFadden (eds.), Amsterdam: North-Holland, pp. 249-67.

Denny, Michael and Melvyn Fuss, 1977, "The Use of Approximation Analysis to Test for Separability and the Existence of Consistent Aggregates, The American Economic Review, 67:3, pp. 404-18.

Frank, Richard G., and David S. Salkever, 1994, "Nonprofit Organizations in the Health Sector," Joumal of Economic Perspectives, 8:4, pp.129-44.

Freeman, Richard, B. and James L. Medoff, 1982, "Substitution Between Production Labor and Other Inputs in Unionized and Nonunionized Manufacturing," The Review of Economics and Statistics, pp. 220-33.

Gagne, Robert, 1990, "On the Relevant Elasticity Estimates for Cost Structure Analyses of the Trucking Industry," Review of Economics and Statistics, pp. 160-63.

Gertler, Paul, J, and Donald M. Waldman, 1992, "Quality-Adjusted Cost Functions and Policy Evaluation in the Nursing Home Industry," Joumal of Political Economy, pp.1232-56.

Gyimah-Brempong, Kwabena, 1987, "Economies of Scale in Municipal Police Departments: The Case of Florida," Review of Economics and Statistics, pp.352-56.

Hamermesh, Daniel S., 1993, Labor Demand, Princeton University Press: New Jersey.

Hamermesh, Daniel S. and James Grant, Fall 1979, "Econometric Studies of LaborLabor Substitution and Their Implications for Policy," The Journal of Human Resources, 14:4, pp.518-42.

Harms, Thelma, Deborah Cryer and Richard Clifford, 1990. Infant/Toddler Environment Rating Scale. New York: Teachers College Press.

Harms, Theima and Clifford, Richard, 1980. Early Childhood Environment Rating Scale. New York: Teachers College Press. 
Howes, Carollee, and Pamela Stewart, 1987, "Child's Play with Adults, Toys and Peers: An Examination of Family and Child Care Influences," Developmental Psychology, 23(3), pp. $423-430$.

Juhn, C., K. Murphy and B. Pierce, 1993, "Wage Inequality and the Rise in Returns to Skill," Joumal of Political Economy, 410-42.

Kennedy, Peter, 1981, "Estimation with Correctly Interpreted Dummy Variables in Semilogarithmic Equations," American Economic Review, 71, p. 801.

Lawrence, Colin, 1989, "Banking Costs, Generalized Functional Forms, and Estimation of Economies of Scale and Scope," Journal of Money, Credit, and Banking, 21:3, pp. 368-79.

Lazar, Irving and Richard Darlington, 1982, "Lasting Effects of Early Education: A Report from the Consortium for Longitudinal Studies," Chicago: University of Chicago Press.

Levy, Frank and R. J. Murnane, 1992, "U.S. Earnings Levels and Earnings Inequality: A Review of Recent Trends and Proposed Explanations," Journal of Economic Literature, 30: 1333-81.

Mocan, Naci H., 1995a, "Structural Unemployment, Cyclical Unemployment and Income Inequality," mimeo, University of Colorado at Denver.

Mocan, Naci H., 1995b, "Quality-Adjusted Cost Functions for Child-Care Centers," The American Economic Review, May 1995, Pp. 409-13.

Mocan, Naci H., John R. Morris and Suzanne Helburn, 1995, "Quality Production Functions for Child Care Centers," mimeo, University of Colorado at Denver.

Moffitt, Robert, 1990, "The Distribution of Earnings and the Welfare State," in Gary Burtless (ed.), A Future of Lousy Jobs? The Changing Structure of U.S. Wages, Washington, D.C. Brookings Institution, pp. 201-30.

Mukarjee, Swati and Ann Dryden Witte, 1993, "Provision of Child Care: Cost Functions for Profit-Making and Not-for-Profit Day Care Centers," Joumal of Productivity Analysis, $4: 145-63$.

Murnane, Richard J., John B. Willett and Frank Levy, 1995, "The Growing Importance of Cognitive Skills in Wage Determination," The Review of Economics and Statistics, pp. 251-66.

Murphy, Kevin and Finis Welsch, 1992, "The Structure of Wages," Quarterly Journal of Economics, pp. 285-325.

Murray, John D. and Robert W. White, 1983, "Economies of Scale and Economies of Scope in Multiproduct Financial Institutions: A Study of British Columbia Credit Unions," The Journal of Finance, XXXVIII:3, pp.887-902. 
Nelson, Randy A., 1985, "Returns to Scale from Variable and Total Cost Functions," Economics Letters, 18:217-76.

Noulas, Athanasios, Subhash Ray, and Stephen Miller 1990, "Returns to Scale and Input Substitution for Large U.S. Banks," Journal of Money. Credit, and Banking, pp.94108.

Powell, Irene and James Cosgrove, Summer 1992, "Quality and Cost in Early Childhood Education," The Journal of Human Resources, 27 : $472-84$.

Preston, Anne, 1993, "Efficiency, Quality and Social Externalities in the Provision of Day Care: Comparisons of Nonprofit and For-Profit Firms," Joumal of Productivity Analysis, 4: 165-82.

Preston, Anne, 1988, "The Effects of Property Rights on Labor Costs of Nonprofit Firms: An Application to the Day Care Industry," The Joumal of Industrial Economics, XXXVI:3, pp. 337-50.

Ramey, Craig and Campbell, Frances., 1991, "Poverty, Early Childhood Education and Academic Competence; The Abecedarian Experiment," in A. Houston, ed., Children in Poverty: Child Development and Public Policy. New York: Cambridge University Press, pp.190-221.

U.S. Department of Commerce, 1992, Who's Minding The Kids? Child Care Arrangements, Fall 1988. Washington, D.C.

Vita, Michael, 1990, "Exploring Hospital Production Relationships with Flexible Functional Forms," Journal of Health Economics, pp. 1-21.

Walker, James R., 1991, "Public Policy and the Supply of Child Care Services," in The Economics of Child Care, David M. Blau (ed.), Russell Sage Foundation: New York.

Wales, Terence J., 1977. "On the flexibility of flexible functional forms: An Empirical Approach," Journal of Econometrics, 5, pp. 183-93

Weisbrod, Burton A. 1988, The Nonprofit Economy; Cambridge, MA: Harvard University Press.

Whitebook, Marcy, Carollee Howes and Deborah Phillips, 1990, "Who Cares? Child Care Teachers and the Quality of Care in America." Final Report of the National

Child Care Staffing Study. Oakland, CA: Child Care Employee Project. 


\begin{abstract}
APPENDIX
A total of 228 infant/toddler classrooms and 521 preschool classrooms were observed to collect information about process quality. Infant/toddler rooms were defined as those where the majority of children were less than two-and-a-half years old. Preschool classrooms were defined as those where the majority of children were at least two-and-a-half years old, but not yet in kindergarten. At each center, two classrooms were randomly chosen: one preschool and one infant/toddler room if the enter served both age groups. No school age or kindergarten classrooms were observed.

In each state, pairs of observers, who were trained in a week-long intensive program, visited each center for one day (from 8:30 a.m. to 3:00 p.m.) to observe the classrooms. They used two well-established global observation instruments to comprehensively assess the day-to-day quality of care provided for children: the Early Childhood Environmental Rating Scale (ECERS) (Harms and Clifford 1980), and its infant/toddler version, the Infant/Toddler Environmental Rating Scale (ITERS) (Harms, Cryer and Clifford, 1990). The ECERS is a 37-item scale organized under seven categories: personal care routines, furnishings and display for children, languagereasoning experience, fine and gross motor activities, creative activities, social development, and adult needs. Each item is scored on a seven point scale from inadequate to excellent. The ITERS is a similar instrument designed to assess center rooms for children from birth to 30 months of age.

In addition, observers used two instruments designed specifically to measure teacher involvement: the Caregiver Interaction Scale (Amett, 1989) which measures the lead teacher's sensitivity, harshness, degree of attachment, and permissiveness; and the Teacher Involvement Scale (Howes and Stewart 1987), which measures the amount and quality of teacher-child interactions. For all four instruments, test of interrater reliability at each site and between sites were very high. ${ }^{19}$

Observers counted classroom staffing ratios and group size five different times throughout the day. They also used the Observations of Activities in Preschool instrument (Palacios and Lera 1991) periodically throughout the day to document the teacher's role in activities, how children were grouped, and the from of expression used during the activity. Finally, they used the UCLA Early Childhood Observation Form

19 The details can be found in "Cost, Quality and Child Outcomes in Child Care Centers, " Technical Report; Center for Research on Economic and Social Policy, University of Colorado at Denver.
\end{abstract}


(Stipek, Daniels, Galuzzo and Milburn, 1992) to differentiate between didactic, structured, and child-centered programs based on five scales: child initiation, academic emphasis, performance pressure, discipline and negative evaluation.

Classroom process describes aspects of the overall quality of the services received by children. More specifically, classroom process refers to the way that children are cared for, such as the amount of warmth a caregiver shows for a child, or the emotional tone that is present in the classroom. The activities that are available for children to engage in, and the learning opportunities that are present, are also aspects of classroom process.

To create a single score to represent classroom process quality, a process quality index was created using principal component techniques. Principal components analyses were performed including both the factor and the total scores from most of the measures of process quality (ECERS, ITERS, Caregiver Interaction Scale, and Adult Involvement Scale). The Peer Play Scale was not included because it was viewed as a measure of child outcomes rather than child care quality. The UCLA Early Childhood Observation Form and the Observation of Activities in Preschool measures were not included because they were not used in infant/toddler classrooms. The principal components analyses were conducted separately for the infant/toddler and preschool data. In both infant/toddler and preschool classrooms, high correlations were observed between the factor scores for each process quality measure and the total scores for each process quality measure. These high correlations indicated that process quality could be indexed by a single score. Thus, the final process index includes the total scores from the ECERS, ITERS, Caregiver Interaction Scale, and Adult Involvement Scale. Separate indices were also computed for infant/toddler and preschool classrooms. The index was scaled to a seven-point scale (similar to the ECERS and ITERS) with a range from l (inadequate, to 3 (minimal), to 5 (good), and to 7 (excellent). Each center's process quality index is a weighted average of room-level indices, weighted by the percent of center FTE children in the given age-group. 
Table A-1

Center Structural Characteristics

\begin{tabular}{|c|c|c|}
\hline Variables & $\begin{array}{l}\text { For-profit } \\
(N=200)\end{array}$ & $\begin{array}{l}\text { Nonprofit } \\
(\mathrm{N}=196)\end{array}$ \\
\hline $\begin{array}{l}\text { Weighted mean staff-child ratio during mid- } \\
\text { morning inside activities. }\end{array}$ & $0.16^{\circ}(0.12)$ & $0.21^{\circ} \quad(0.16)$ \\
\hline Weighted mean group size & $12.71 \quad(8.28)$ & $12.72(5.90)$ \\
\hline Rate of staff turnover & $45.58^{\circ}(44.41)$ & $30.02^{\circ}(36.28)$ \\
\hline Weighted Average Age of Teaching Staff & $31.56^{\circ} \quad(5.44)$ & (6.26). \\
\hline $\begin{array}{l}\text { Weighted Average Prior Child Care Experience } \\
\text { of Teaching Staff (in years) }\end{array}$ & $2.87^{*} \quad(2.30)$ & $3.65^{\circ} \quad(2.47)$ \\
\hline $\begin{array}{l}\text { Percent Teaching Staff with } 16 \text { and more years of } \\
\text { Education }\end{array}$ & $0.26(0.26)$ & $(0.23)$ \\
\hline $\begin{array}{l}\text { Weighted Average Tenure of Teaching Staff (in } \\
\text { months) }\end{array}$ & $31.64^{\circ} \quad(28.84)$ & $48.31^{*} \quad(35.46)$ \\
\hline Percent Infants & $0.25^{\circ}(0.23)$ & $0.18 \quad(0.23)$ \\
\hline Age of the Center (in years) & $10.31^{\circ}(8.31)$ & $16.12^{*}(14.66)$ \\
\hline
\end{tabular}

The first value in each cell is the mean. The number in parenthesis is the standard deviation. (*) indicates that the means between for-profit and nonprofit centers are different at the $5 \%$ level. 
Table A-2

Translog Cost Functions for centers that employ all three labor categories

\begin{tabular}{|c|c|c|c|}
\hline VARIABLE & PARAMETER & COEFFICIENT & t-STATISTIC \\
\hline Constant & $\alpha_{0}$ & $12.600^{\circ}$ & 199.490 \\
\hline Wagel & $\alpha_{1}$ & $0.234^{\circ}$ & 17.740 \\
\hline Wage2 & $\alpha_{2}$ & $0.335^{\circ}$ & 21.969 \\
\hline Wage3 & $\alpha_{3}$ & $0.243^{\circ}$ & 17.619 \\
\hline Infant-toddler & $\pi_{1}$ & $0.330^{*}$ & 8.910 \\
\hline Preschool & $\pi_{2}$ & $0.254^{\circ}$ & 4.957 \\
\hline Schoolage & $\pi_{3}$ & $0.100^{\circ}$ & 3.273 \\
\hline Infant* Preschool & $\xi_{12}$ & -0.001 & -0.058 \\
\hline Infani*Schoolage & $\xi_{13}$ & 0.000 & 0.029 \\
\hline Preschool*Schoolage & $\varepsilon_{23}$ & 0.000 & -0.059 \\
\hline Infant-toddler ${ }^{2}$ & $\xi_{11}$ & 0.002 & 0.058 \\
\hline Preschool $^{2}$ & $\varepsilon_{22}$ & 0.002 & 0.058 \\
\hline Schoolage ${ }^{2}$ & $\varepsilon_{33}$ & 0.001 & 0.058 \\
\hline Wagel $^{2}$ & $\gamma_{11}$ & $0.213^{\circ}$ & 3.555 \\
\hline Wage2 ${ }^{2}$ & $\gamma_{\boldsymbol{n}}$ & $0.273^{*}$ & 3.367 \\
\hline Wage $3^{2}$ & $\gamma_{33}$ & 0.089 & 1.715 \\
\hline Wagel *Wage2 & $\gamma_{12}$ & $-0.251^{\circ}$ & -4.588 \\
\hline Wagel *Wage3 & $\gamma_{13}$ & -0.015 & -0.363 \\
\hline Wage2*Wage3 & $\gamma_{23}$ & 0.038 & 0.751 \\
\hline Space & $\beta_{1}$ & $0.172^{*}$ & 3.178 \\
\hline Space $^{2}$ & $\beta_{2}$ & 0.062 & 1.270 \\
\hline Wage 1*Space & $\delta_{1}$ & 0.006 & 0.486 \\
\hline
\end{tabular}




\begin{tabular}{|c|c|c|c|}
\hline \multicolumn{4}{|c|}{ (Table A-2 continued) } \\
\hline Wage2*Space & $\delta_{2}$ & 0.007 & 0.460 \\
\hline Wage3*Space & $\delta_{3}$ & -0.018 & -1.369 \\
\hline Wage1 *Infant-toddler & $\mu_{18}$ & 0.000 & 0.058 \\
\hline Wage1*Preschool & $\mu_{12}$ & 0.000 & -0.058 \\
\hline Wage1*Schoolage & $\mu_{13}$ & 0.000 & -0.058 \\
\hline Wage2*Infant-toddler & $\mu_{21}$ & 0.000 & -0.057 \\
\hline Wage2*Preschool & $\mu_{22}$ & 0.000 & -0.052 \\
\hline Wage2*Schoolage & $\mu_{21}$ & 0.000 & -0.058 \\
\hline Wage3*Infant-1oddler & $\mu_{31}$ & 0.000 & -0.058 \\
\hline Wage3*Preschool & $\mu_{32}$ & 0.000 & 0.058 \\
\hline Wage3*Schoolage & $\mu_{33}$ & 0.000 & 0.058 \\
\hline Space*Infant-toddler & $\Phi$ & 0.000 & 0.059 \\
\hline Space*Preschool & $\Phi$ & -0.001 & -0.057 \\
\hline Space*Schoolage & $\Phi$ & 0.000 & 0.055 \\
\hline Quality & $\tau_{1}$ & $0.415^{*}$ & 2.907 \\
\hline Quality $^{2}$ & $\tau_{2}$ & 0.536 & 0.850 \\
\hline Quality *Space & $\tau_{3}$ & 0.055 & 0.425 \\
\hline Quality *Wage1 & $\mathbf{n}_{1}$ & $-0.178^{\circ}$ & -3.985 \\
\hline Quality *Wage2 & $\mathbf{n}_{2}$ & 0.066 & 1.289 \\
\hline Quality*Wage3 & $\mathbf{n}_{3}$ & $0.131^{\circ}$ & 2.796 \\
\hline Quality ${ }^{*}$ Infant-toddlers & $\psi_{1}$ & 0.001 & 0.057 \\
\hline Quality*Preschool & $\psi_{2}$ & 0.003 & 0.058 \\
\hline Quality *Schoolage & $\psi_{3}$ & -0.001 & -0.058 \\
\hline
\end{tabular}




\begin{tabular}{|c|c|c|c|}
\hline \multicolumn{4}{|c|}{ (Table A-2 concluded) } \\
\hline Profit & $\omega_{1}$ & -0.010 & -0.245 \\
\hline Specreg & $\boldsymbol{\omega}_{\mathbf{2}}$ & 0.110 & 1.359 \\
\hline Pubsupp & $\omega_{3}$ & 0.077 & 0.956 \\
\hline Pubausp & $\omega_{4}$ & 0.036 & 0.467 \\
\hline National Chain & $\omega_{s}$ & $-0.123^{\circ}$ & -2.189 \\
\hline California & $\omega_{6}$ & -0.107 & -1.840 \\
\hline Colorado & $\omega_{1}$ & -0.068 & -1.408 \\
\hline North Carolina & $\omega_{\mathrm{B}}$ & $-0.153^{\circ}$ & -2.598 \\
\hline Box-Cox Parameter & $\lambda$ & 0.003 & 0.058 \\
\hline
\end{tabular}

* Statistically significant at the 5 percent level. $\mathrm{N}=225$. 